\title{
Entrepreneurship through Micro Finance in North East India: A Comprehensive Review of Existing Literature
}

\author{
Sanjay Kanti Das \\ Lumding College, Lumding, Nagaon, Assam, India \\ sanjay19711123@rediffmail.com
}

\begin{abstract}
Entrepreneurship on small scale is the only solution to the problems of unemployment and proper utilization of both human and non-human resources and improving the living conditions of the poor masses. The basic rationale of developing these industries are that they provide immediate large scale employment, ensure more equitable distribution of income, encourage decentralization of industries and eradicate poverty and unemployment. During the last three decades, many countries of the world have experienced the need and importance of entrepreneurship has been accepted as a strategy to achieve the twin objectives of promotion of entrepreneurship, particularly among the educated unemployed youth and also for rapid industrialization in the economy. The main object of this paper is to study the existing literature on entrepreneurship through Micro finance-SHG linkage in India in general and NER in particular. The analysis of this study is based on secondary sources. Efforts are also made in this paper to analyze the role of micro finance through SHGs in the promotion and development of entrepreneurship. This paper examines the different approaches of entrepreneurship and also explains the different key areas of micro enterprise development. Finally, this paper highlights the problems of micro, rural and women entrepreneurs and also suggested some specific measures based on the survey of existing literature, for the promotion of these industries in the country.
\end{abstract}

Keywords: Entrepreneurship, Micro finance, Micro Entrepreneur, North Eastern Region, Rural Entrepreneur, Women Entrepreneur

\section{Introduction}

Entrepreneurship plays a vital role in the growth of an economy. Entrepreneurship development has been accepted as one of the strategy to achieve the objective of promotion of entrepreneurship for solving the problem of unemployment and rapid industrialization (Mali, 2000). The development of small and micro industries has been accepted as one of the most significant and important feature of industrial development in India. Entrepreneurship on small scale sector is the only solution to the problem of unemployment and proper utilization of both human and non-human resources and improving the living condition of the poor masses (Singh, 2009). The basic rationale of developing these industries are that they provide immediate large scale employment, ensure more equitable distribution of income, encourage decentralization of industries and eradicate poverty and unemployment in an economy. In brief, a country which is rich in entrepreneurship can attain economic augmentation (Nazar, 2005).The economic history of the developed countries tends to support the fact that the economy is an effect for which entrepreneurship is the cause (Khanka, 2004). The important role played by the entrepreneurs in the development of Western Countries has made the people of underdeveloped countries too much conscious on the significance of entrepreneurship for economic development. Now, the people have begun to realize that for achieving the goal of economic development, it is necessary to increase entrepreneurship both qualitatively and quantitatively in the country. It is only the entrepreneurs who fully explore the potentialities of the country's available resources, labor, technology and capital. Schumpeter, visualized the entrepreneurs as the key figures in economic development because of their role in introducing innovations (Khanka, 2004).Parson and Smelser, described entrepreneurship as one of the two necessary conditions of economic development, the other being the increased output of capital (Parson \& Smelser, 1956).During the last three decades, many countries of the world have experienced the need of entrepreneurship development as means of solving the problem of unemployment and industrialization. The need for a broad based entrepreneurial call in India arises from the need to speed up the process of activating the factors of production, leading to a higher rate of economic growth, dispersal of economic activities, development of tribal and backward areas, creation of employment 
opportunities, improvement of standard of living of the weaker sections of the society and involvement of all sections of the society in the process of growth.

The main objective of this paper is to study the existing literature on entrepreneurship through Micro Finance in India in general and North Eastern Region (henceforth NER) in particular. The specific objectives of this paper includes-

- To study the existing literature on entrepreneurship through micro finance particularly Self Helps Groups (henceforth SHG) in respect to women entrepreneurship in India and NER in particular.

- Another objective is to access the status of women entrepreneurs in India and NER in particular on the basis of survey of existing literature.

- Another objective is to study the existing literature on micro \& rural entrepreneurs in NER and India.

- To identify the major areas of micro enterprise development and to chalk out the strategies for micro enterprise development is another significant objective of this paper.

- To identify the problems of rural, micro and women entrepreneurs based on survey of literature is another objective of this study.

\section{Entrepreneurship and Micro Finance: Different Approaches}

The approaches for delivering services of microfinance for entrepreneurship can be classified under four broad categories:

(a) Self-Help Group Promotion Approach: This approach is based on the principle that the NGO promotes SHGs and arranges credit from the banks .The NGO will provide necessary financial and supportive assistance to the promoted SHGs as a financial advisor. This ultimately leads to build the capacity of SHGs in terms of savings mobilization, linking them with banks and providing technical support in starting the viable micro enterprises by the SHG members. In this approach, NGO basically forward the role of intermediating agency between SHGs and Banks.

(b) Minimalist Approach of Micro Finance Institutions (MFI): Under this approach the specialized financial institutions like Small Industries Development Bank of India (SIDBI), RMK and other donor agencies provide bulk lending, soft loans and special assistance to those NGOs which can act as MFI by lending money to the poor people under the concept of SHGs. The examples of such MFIs are SEWA Bank \& FWWB in Gujarat, BASIX in Andhra Pradesh, and RGVN in Assam etc.

(c) Micro Enterprise Development Approach: The Government of India (after words GOI) established many developmental and promotional institutions for the promotion of micro enterprises like Indian Institute of Entrepreneurship, Medium, Small and Marginal Enterprises (MSME) etc. These institutions are engaged to organize 'Entrepreneurial Development Programmes'. To make EDP successful and effective, the role of the NGOs has significant in terms of identification of place or location, promotional activities, selection of potential entrepreneurs, entrepreneurial training, monitoring and follow-up action.

(d) Social Development Approach: The social development approach of micro finance is based on the premise that people should earn more money by investing in the viable micro enterprises. The share of the profit should be spent on social development i.e. health, education, housing, drinking water, sanitation etc. By earning profit from the micro enterprises people will increase their paying ability for services being delivered to them under different projects of social development run by NGOs and State/Central Government.

Women Entrepreneur, Empowerment and SHG: Women comprise half of human resources. They have been identified as key agents of sustainable development and women's equality is as central to a more holistic approach towards destabilizing new patterns and process of development that are sustainable (Jha, 2009). Women as entrepreneurs have become an integral part of national development planning and strategies (Tuladhar, 1996). The contribution of women and their role in the family as well as in the economic development and social transformation are pivotal. This fact is ignored to some extent in the developing economy like India which resulted gender discrimination and this fact corroborates that 
India's position in respect of Gender Related Index. According to UNDP-HDR, 1997 gender disparity can be seen through the lens of the Gender Related Development Index and Gender Empowerment Measure. India's position is too low in the world and consequently, the GOI, under $9^{\text {th }}$ Plan adopted for women empowerment as one of the objective of economic planning (GOI, 2001).It is reported from a study that women constitute 90 per cent of total marginal workers of the country. Rural women who are engaged in agriculture form 78 per cent of all women in regular work (Sathiabama, 2010). Therefore, to cover up this segment of population, constant efforts should be taken to provide the benefits of planned development. Consequently for achieving the goal of women empowerment government was widely accepted the SHGBank Linkage Micro Finance Programme in 2001 and ultimately Govt. established Rashtriya Mahila Kosh, Indira Mahila Yojanaetc. To focus on promoting women SHGs.Now how far the working of SHG-Bank Linkage Programme is successful in empowering the women is yet a matter of controversy.

A lot of evaluation studies were made to identify the impact of micro finance and SHGs on women empowerment in the country. Some of the important evaluation studies are incorporated here in this paper to access the role of SHGs in women empowerment.Micro finance has evolved over the past quarter century across India into various operating forms and found varying degree of success (Reddy, 2005). One such form of Micro Finance has been the development of the self-help movement. Based on the concept of 'Self Help' small groups of women have formed into groups and operate a 'savings first business model' where by the members' savings are used to funding loans. The results of these SHGs are promising and have become a focus of intense examinations as it is proving to be an effective method of poverty reduction.SHGs can make women to contribute in the economy. It has changed the lives of many in India. Group Power has been found to be patent force in giving collective empowerment \& voice to the poor women in rural areas, but has not necessarily empowered them beyond the confines of patriarchy (Smita, 2006).There is a long way to go before re-orientation of power relationships both in the household and at the societal level. Therefore, empowerment of poor rural women will be possible only if they are trained and imparted skills for a certain employment (Sundari, and Geetha, 2000).National Commission for Women, 2004 reveals that 30\% of the household reported increase in assets after joining SHG mainly in Rajasthan and Tamil Nadu. Wadiniale, 2004 reported that slum women are empowered by saving credit programme in India. The study also reported that SHG programme has increase in monthly household income, 66\% women converted their houses into permanent structure and many positive impact on health, social and cultural values. Further, a few studies (Wadiniale, 2004 and Singh, 2011) reveals that there was a drastic change in social status of women after joining the SBLP and articulated SHG as a change agent for social and economic empowerment of rural poor particularly women. Bokil, (2005)reported that SHGs were the best place to address the issues of domestic violence and also forwarded arbitration in domestic quarrels and disputes, counseling, facilitation of legal action and also provide moral and motivational support to the victim.

Mukerjee, (2006) reported that SHGs have positive impact on economic, political, household decision making and awareness level of the members with respect to social and health issues. Meher, (2003) and Ravi \& Venkataramana, (2002) reported that SHGs have a positive impact on elimination of poverty and act as an instrument for empowerment of women through economic intervention. Siwa, (2008) reported that the Kudumbashree initiative of the Govt. of Kerala have positive impact on economic empowerment and development of micro enterprise development among the rural women. Gurumoorthy, (2002) reported that SHGs has the power to create a social- economic revolution in the rural areas of the country and can act as an important tool for socio-economic empowerment of the poor, particularly women (Roy, 2011). It is also reported that the members of SHGs are prepared to undertake entrepreneurial activities at a smaller level with minimum capital requirements (Kamaraj, 2005) and can promote self-employment opportunities to the rural women (Manimekalai and Rajeswari, 2000). They reported that women SHG members who took up their own enterprise were contributing more than $50 \%$ of their earnings to the households in Andhra Pradesh. Further, National Institute of Rural Development (NIRD) on SHG in 2004 (Das, 2010) reported that about $25 \%$ of members of SHGs have taken micro enterprises and generated income of more than Rupees 1000/1500 p.m. The study further reveals that about $85 \%$ of the members have awareness about various programmes and activities on health, education, water and sanitation and legal rights. Moreover, more than $82 \%$ of the members reported that they are sending to their kid to school and hence, the members of SHG are both socially and economically independent after joining SHGs. Pati and Lyngdoh, (2011) reported that micro finance through SHGs has had a positive impact on income, expenditure and savings of the women clients in Meghalaya. The same observation is also revealed by Aruna \& Jyothirmayi, (2011)in case of Hyderabad and also reported considerable improvement in self- 
worthiness and decision making level of women members because of participation. Meetei, (2011) reported that micro finance through SHGs which promotes during the last 10 years in Manipur increases average monthly income earning capacity and in turn, saving capacity and effective productivity of SHG members and have ensured better economic life of rural women in Manipur.

Centre for Micro Finance \& Livelihood, (2009) in a survey in Arunachal Pradesh reported "though the Micro finance through SHGs has a positive impact but due to low population density, lack of information and training etc. the progress of the movement is not up to the mark". Rajendra and Raya (2010) reported that the micro finance through SHG have brought higher psychological and social empowerment than economic empowerment. The study reveals that there is a definite improvement of managerial skills, psychological wellbeing and social empowerment among rural women as a result of participating in SHG linkage programme in Tamil Nadu. Finally, APMAS, 2009reported that SHG programme in the state of Assam resulted significant social and economic benefits and the study categorically mentioned that $75 \%$ of the group members has experienced with increase in saving habits and income, increase in access to formal credit and decline in family debts etc. Micro Finance through SHGs is an important tool for socioeconomic empowerment of the poor, particularly women (Roy, 2011). It is viewed that the movement of SHGs will transform through a process of transformation of individual selves \& their empowerment from 'disempowerment' (Hariss, 2010). A large number of evaluation studies reported that after the onset of SHGs, women had better access to assets \& resources, developed better leadership skills, awareness regarding health and education aspects, communication skills, and improved financial literacy among women and were able to tackle the issue of injustice and family violence (Reddy, 2002 \& Ramesh, 2004).Another significant contribution of micro finance through SHGs is the promotion of women entrepreneurship (Titus, 2002 \& Purushotham, 2004).So many evaluation studies reported that women entrepreneurs who have started small entrepreneurs through SHGs expand them into large scale units even then a large number of problems lagging them. Some researcher observed that micro credit intervention benefited many women entrepreneurs in terms of shifting from wage to self-employment, increased income, repayment of old debts, purchase of assets, sending of kids to schooling etc. .Micro credit intervention through SHGs also reduces the gender disparity in access to institutional credit. A lot of research studies reported that gender disparity is gradually narrowing down over the years because of the promotion of SHGs (Sundari, and Geetha, 2000)

Micro Finance industry in the North Eastern Region is in initial stage. Micro Finance is witnessing a faster growth in the region except Arunachal Pardesh and Sikkim whereinit is reflected a growing trend of Micro Finance Providers with high volume of finance disbursement. Many national level MFIs are also emerging in the NER recently. (Das, 2010; Das, 2011; Singh, 2009)It is also reported that the assess and availability of micro credit through SHGs has not only resulted in higher incomes of women but also developed better leadership skills, awareness regarding health and education aspects, communication skills, and improved financial literacy among women in the North Eastern region of India.(Pati \& Lyngdoh, 2011; Singh, 2009; Meetei, 2011). The role of micro-credit is to improve the social and economic development of women and improve the status of women in households and communities. To highlight the true picture of micro finance under its two different models in the field of women's position a brief note here followed with the data relating to the state of micro finance in India. The Table 1 shows the position of women SHGs in India during the last years. Further, it is observed form the Table 1 that about $80 \%$ of the SHGs functioning in the country are women owned SHGs. It is further realized that out of the total savings linked and credit linked SHGs, SHGs (exclusive women) saving linked and credit linked with banks were $79.5 \%$ and $85.4 \%$, respectively. Further, the percentage of loans outstanding in case of women SHGs (exclusively women) to the total SHGs which was $78.45 \%$ as on $31^{\text {st }}$ March, 2008 which had increased to $81.93 \%$ as on $31^{\text {st }}$ March, 2009 and $80.3 \%$ as on $31^{\text {st }}$ March,2010.

Economic development is one of the factors that have changed the entire scenario of social \& cultural environment within the country especially for the women. The rural women are engaged in small scale entrepreneurship programme with the help of SHGs. It is observed from the survey of literature that Micro Finance and SHGs are directly or indirectly empower the women folk of the country. It is further observed that in the NER of India, only a few studies were conducted to evaluate the role of micro finance through SHGs with respect to women empowerment. However, from the survey of existing literature, it is observed from a few studies that SHGs were basically initiated to empower women economically and through self-employment activities. These groups were also considered as a viable alternative for women to take up entrepreneurial activities with the help of micro credit. 
Table 1: Position of Women SHGs (Rupees in Crores)

\begin{tabular}{|c|c|c|c|c|c|c|c|}
\hline \multirow[t]{2}{*}{ Particulars } & \multirow[t]{2}{*}{ Year } & \multicolumn{2}{|c|}{ Total SHGs } & \multicolumn{2}{|c|}{$\begin{array}{c}\text { Exclusive Women } \\
\text { SHGS }\end{array}$} & \multicolumn{2}{|c|}{$\begin{array}{c}\text { \% of Women SHGs to } \\
\text { Total SHGs }\end{array}$} \\
\hline & & Number & $\begin{array}{l}\text { Amount } \\
\text { (Rupees) }\end{array}$ & Number & $\begin{array}{l}\text { Amount } \\
\text { (Rupees) }\end{array}$ & Number & $\begin{array}{l}\text { Amount } \\
\text { (Rupees) }\end{array}$ \\
\hline \multirow{3}{*}{$\begin{array}{l}\text { Savings } \\
\text { linked with } \\
\text { SHGs }\end{array}$} & 2007-08 & 5005794 & 3785.39 & 3986093 & 3108.65 & 79.57 & 82.12 \\
\hline & 2008-09 & 6121147 & 5545.62 & 4863921 & 4434.03 & 79.46 & 79.96 \\
\hline & $2009-10$ & 6953250 & 6198.71 & 5310436 & 4498.66 & 76.4 & 72.6 \\
\hline \multirow{3}{*}{$\begin{array}{l}\text { Loan } \\
\text { Disbursed }\end{array}$} & 2007-08 & 1227770 & 8849.26 & 1040996 & 7474.26 & 84.79 & 84.46 \\
\hline & 2008-09 & 1609586 & 12253.51 & 1374579 & 10527.38 & 85.39 & 85.91 \\
\hline & $2009-10$ & 1586822 & 14453.30 & 1294476 & 12429.37 & 81.60 & 86.0 \\
\hline \multirow{3}{*}{$\begin{array}{l}\text { Loan } \\
\text { Outstanding }\end{array}$} & 2007-08 & 3625941 & 16999.91 & 2917259 & 13335.61 & 80.46 & 78.45 \\
\hline & 2008-09 & 4224338 & 22679.84 & 3277355 & 18583.34 & 77.58 & 81.93 \\
\hline & $2009-10$ & 4851356 & 28038.28 & 3897797 & 23030.36 & 80.3 & 82.1 \\
\hline
\end{tabular}

Source: Compiled from NABARD Reports and Status of Micro Finance in India, 2007-08; 2008-09 and 2009-10

\section{Women Enterprises and SSI Units Managed by Women in NER \& India}

The total number of women enterprises in the SSI Sector was estimated at 10,63,721. The estimated number of enterprises actually managed by women was 9, 95,141. In the States of Mizoram, Orissa, Karnataka, Goa, Lakshadweep, Kerala, Tamil Nadu and Pondicherry, the share of women employment was significantly higher (more than $20 \%$ )[MSME, 2010]. It is also observed from Table 2 that Assam represents more women owned enterprises and also engaged a large number of women employees in both registered and unregistered sector in comparison to other NER states. However, in Assam the percentage of female employment in the total employment is comparatively lower (6.08\%) than the other NER states. Among the NER states Mizoram recorded highest percentage of female employee in the total employment. Further, the said percentage of female employment at the national level is $13.31 \%$ which is much higher than the State of Assam and Nagaland.

Table 2: Participation of Women in Management/Ownership in SSI Sector

\begin{tabular}{lllll}
\hline $\begin{array}{l}\text { Name } \\
\text { of State/ UT }\end{array}$ & $\begin{array}{l}\text { No. of Enterprises } \\
\text { ManagedBy } \\
\text { Women }\end{array}$ & $\begin{array}{l}\text { No. of Women } \\
\text { Enterprises }\end{array}$ & $\begin{array}{l}\text { No. of Female } \\
\text { Employees(Both } \\
\text { Registered } \\
\text { Unregistered sector) }\end{array}$ & $\begin{array}{l}\text { Percentage of Female } \\
\text { employment in the } \\
\text { andal } \\
\text { employment of the } \\
\text { State/UTs }\end{array}$ \\
\hline $\begin{array}{l}\text { Arunachal } \\
\text { Pradesh }\end{array}$ & 131 & 150 & 446 & 12.10 \\
$\begin{array}{l}\text { Assam } \\
\text { Manipur }\end{array}$ & 11189 & 11757 & 26065 & 6.08 \\
Meghalaya & 3658 & 10745 & 23338 & 17.06 \\
& & 3580 & 8803 & 13.42 \\
Mizoram & 3076 & 3700 & 6824 & 27.46 \\
& & & & 5.65 \\
Nagaland & 207 & 179 & 3211 & 16.72 \\
Sikkim & 30 & 98 & 221 & 13.38 \\
Tripura & 631 & 863 & 7619 & 13.31 \\
All India & 995141 & 1063721 & 3317496 & \\
\hline
\end{tabular}


The total number of female employees in the SSI sector is estimated at 33, 17,496. About $57.62 \%$ of the female employees were employed in the SSI units located in the States of Tamil Nadu, Kerala, Karnataka, West Bengal and Andhra Pradesh. The proportion of female employees in the total employment in the SSI sector was of the order of $13.31 \%$. In the States of Mizoram, Orissa, Karnataka, Goa, Lakshadweep, Kerala, Tamil Nadu and Pondicherry, the share of women employment was significantly higher (more than $20 \%$ ) compared to the total employment in the respective States (Table 2). From the Table 3, it is seen that about $13 \%$ of the women enterprises were in the registered SSI sector and the remaining $87 \%$ were in the unregistered SSI sector. With regard to the enterprises managed by women, $11.5 \%$ were in the registered SSI sector and $88.5 \%$ were in the unregistered SSI sector.In the NER-India, thousands of people are pushing micro enterprises into profitable business ventures, thereby turning around the regions rural economy. There are more than 90000 SHGs working in diverse fields in rural Assam- this high mark number being an indicator of the success of the Central Government aided venture in working towards development and boosting the rural economy. Table 6 depicts the physical progress of SHGs underSwarnjayanti Gram Swarozgar Yojana (SGSY) schemes in India, where form it is observed that approximately $15 \%$ of SHGs under the SGSY scheme in the country created IGA or micro enterprises. The concept of SHGs got a major impetus after the launching of SGSY - a central Govt programme aimed at bringing families above the poverty line by ensuring a sustainable level of income over a period of time. Government of Assam on December 6, 2009 formally launched the Chief Minister's Micro Finance Scheme 'Khudra Reen' under which the Govt made available a fund of Rupees10 Crores to Assam Financial Corporation which is the implementing agency for the scheme. It is observed that the Government has given maximum stress on micro financing for solving the unemployment problem and to help rural poor who cannot avail any financial assistance from financial institutions or banks. The poor people particularly the women section has traditionally not been recognized as creditworthy or able to save and thus, they are not perceived to be a profitable market for credit.The MSME sector is a significant contributor to the Indian economy. Based on official figures from the Ministry of MSME, November 2008, this sector contributes $8 \%$ of National GDP, comprises $50 \%$ of India's total manufactured exports, $45 \%$ of India's total industrial employment and $95 \%$ of all industrial units. The SME sector in India, however, has been changing over time, mostly through changes in government policy.

The MSME sector in India has witnessed significant changes in the post liberalization period since 1991. It is observed that the number of registered and unregistered firms in the Indian MSME sector from 1990 to 2003 is quite promising. The first feature is that this sector has been growing steadily throughout this period. In 1991 there were 67.07 lakhs MSMEs in the country which climbed to 113.95 lakhs by 2003 which further rose to 210 lakhs (approx)by the end of 2009.It is further observed that the growth rate for the overall industry and the unregistered segment is steady and close to 4 percent. The growth of registered sector, however, has high variance. This ranges from 14 percent growth to negative growth in few years. Except for the five years from 1995-2000, in the remaining period, the registered sector has had very high growth rates compared to the unregistered segment. It is also observed that almost throughout the post liberalization period, the SME sector has been growing significantly faster than the total industrial sector. In 2005-06, the SME sector grew at an impressive $12.32 \%$ while the total industrial sector grew at $8.1 \%$. The average annual growth rate of the sector (1991-2006) was $8.47 \%$ as compared to the growth rate of the total industrial sector which was $6.07 \%$ over the same period (Annual Reports, Ministry of Small Scale Industries, 2006).If we look at the small and micro enterprises of NER of India, it is observed that most of the small and micro enterprises are in the tertiary sector. The tertiary sector in the NER is largely based on the activities generate through external assistance and not by the primary and secondary activities in the states within. Further, most of the IGA or SSI units in the country are in the unregistered sectors. This diverse nature has shown the different style of entrepreneurship and growth scenario of the small scale and village industries in the country including the women enterprises Table 3.

Table 3: Classification of SSI units in India on the basis of Registration

\begin{tabular}{llll}
\hline Characteristic & $\begin{array}{l}\text { Registered Units } \\
\text { (Rupees in Lakhs) }\end{array}$ & $\begin{array}{l}\text { Unregistered Units } \\
\text { (Rupees in Lakhs) }\end{array}$ & $\begin{array}{l}\text { Total } \\
\text { (Rupees in Lakhs) }\end{array}$ \\
\hline Men & $12.37(13.08)$ & $82.20(86.92)$ & $94.57(100)$ \\
Women & $1.38(12.93)$ & $9.26(87.07)$ & $10.64(100)$ \\
\hline
\end{tabular}




\begin{tabular}{lll}
\hline Total & 13.75(13.07) & 9.26(86.93)
\end{tabular}

(Figures in brackets represent percentages to total)

Source: Compiled from Ministry of Small Industry, GOI. 2006

The gender-wise distribution of entrepreneurs in the NER, first of all, indicates that the percentage of male entrepreneurs is far more than the female entrepreneurs in all the NE States and both sectors- rural and urban Table 4.

Table 4: Gender and Area wise Entrepreneurship Profile in NER (As on March, 2006)

\begin{tabular}{lllll}
\hline \multirow{2}{*}{ States } & \multicolumn{4}{l}{ Percentage No. Of Units in rural areas Managed by } \\
\cline { 2 - 5 } & \multicolumn{3}{l}{ Male } & \multicolumn{2}{l}{ Female } \\
\cline { 2 - 5 } & Rural & Urban & Rural & Urban \\
\hline Arunachal Pradesh & 49.41 & 30.59 & 7.06 & 12.94 \\
Assam & 40.46 & 46.07 & 7.85 & 5.63 \\
Manipur & 41.77 & 42.27 & 11.24 & 4.72 \\
Meghalaya & 44.01 & 22.96 & 23.74 & 9.29 \\
Mizoram & 7.69 & 65.63 & 2.12 & 24.56 \\
Nagaland & 18.52 & 68.08 & 2.12 & 11.29 \\
Sikkim & 34.48 & 48.28 & 5.75 & 11.49 \\
Tripura & 52.45 & 41.92 & 2.92 & 2.71 \\
All India & 39.83 & 51.85 & 4.50 & 3.82 \\
\hline
\end{tabular}

Source: Compiled from Mishra (2007).Recent Trend of Village and Small Enterprise.

The percentages of number of units in rural areas in India are managed by male and female are $39.83 \%$ and $4.50 \%$ respectively. The States like Mizoram and Nagaland shows a comparatively lower percentage share of the units managed by men in rural areas, while the states like Tripura, Mizoram and Nagaland shows a comparatively lower percentage of SSI units in rural areas managed by female. However, among the states of NER, Manipur and Meghalaya shows a remarkable progress in the field of setting up of economic units under SSI in rural areas by the women. In Meghalaya, which is inhabited mostly by the tribes that are matrilineal and perhaps multifocal too, the male entrepreneurship far exceeds the female entrepreneurship, although the latter is more prominent there than elsewhere in the NER. In the urban areas of Sikkim, Arunachal Pradesh, Nagaland and Mizoram, female entrepreneurs are more in proportion than those in the rural areas, which indicate that urbanization and economic development have worked in favor of gender equality in economic spheres. In Arunachal Pradesh, Manipur, Tripura and Meghalaya rural entrepreneurship is more vivid, indicating the spread of industrial development beyond urban areas. Again in Mizoram and Nagaland, urban entrepreneurship dominates the scene and it appears that the rural areas have remained unattractive. Moreover, it evident from the fact that most of the women enterprises in the NER States are unregistered which is similar with the all India pattern. It is observed from Table 5 that the percentage of women in SSI units (unregistered sector) in the NER is only $2.7 \%$. Further, among the NER states, Manipur represents the highest percentage of women participation in SSI in both registered and unregistered sector.

Table 5: Participation of Women in SSI Sector (As on March, 2008)

\begin{tabular}{lllll}
\hline States & \multicolumn{2}{l}{ Unregistered } & Registered & \\
\cline { 2 - 5 } & $\begin{array}{l}\text { Enterprises } \\
\text { managed by women }\end{array}$ & $\begin{array}{l}\text { Women } \\
\text { enterprises }\end{array}$ & $\begin{array}{l}\text { Enterprises } \\
\text { managed by women }\end{array}$ & $\begin{array}{l}\text { Women } \\
\text { enterprises }\end{array}$ \\
\hline $\begin{array}{l}\text { Sikkim } \\
\text { Arunachal }\end{array}$ & 0 & 53 & 30 & 45 \\
Pradesh & 80 & 87 & 51 & 63 \\
Nagaland & 130 & & & \\
Manipur & 8434 & 122 & 77 & 57 \\
Mizoram & 2346 & 9980 & 734 & 765 \\
Tripura & 578 & 3007 & 730 & 693 \\
Meghalaya & 3018 & 784 & 53 & 79 \\
Assam & 9241 & 2929 & 640 & 651 \\
\hline & & 9716 & 1948 & 2041 \\
\hline
\end{tabular}




\begin{tabular}{lllll}
\hline NER & 23827 & 26678 & 4263 & 4394 \\
All India & 880780 & 926187 & 114361 & 137534 \\
\hline
\end{tabular}

Source: Compiled from NEC databank, 2008.

\section{Micro and Rural Entrepreneurship and SHGs}

The term 'micro-enterprise' refers to a very small-scale, informally organized business activity undertaken by poor people. According to Schreiner \& Woller, (2003) Micro-enterprises are tiny businesses; most have one employee, the owner. Micro enterprise refers to an enterprise where investment in plant and machinery does not exceed Rupees 25 lakhs. Rural entrepreneurship means establishing industrial units in the rural areas. It is an effective means of accelerating the process of rural development. Micro Enterprise is a proven way to strengthen viable small businesses resulting in increased household income and savings and thus, alleviating the crunch of economic poverty (Biswas, \& Sengupta, (2009).Micro enterprise sector is very diverse in terms of its size, type, market and several other characteristics that it is difficult to define a boundary for micro enterprise and define it in proper words. Probably, this is the predominant reason behind lack of official definition for micro enterprise.In many developing countries microenterprise in its various forms are the major sources of livelihood in rural as well as urban areas. It contributes to a large proportion of employment generation in developing as well as developed countries. Microenterprises are considered to be the source of equitable distribution. Micro enterprise is a source of income and employment for poor people where no other alternatives are available for them. In urban areas, a growing percentage of the working populationsometimes as high as 50 percent- is engaged in microenterprise activity (Otero and Rhyne, 1994).In a study on the role of microfinance, entrepreneurship and sustainability in poverty alleviation in least developed countries Vincent, (2004) concluded that microfinance and sustainable micro entrepreneurship in LDC's have economic benefits and it affect the quality of life for the microentrepreneurs. Other than economic benefits, there are some special benefits of micro enterprise \& micro finance development (Singh, 2002).

Micro credit is promoting the small scale business enterprises and its major aim is to alleviate poverty by income generating activities among women and poor. Therefore, they could achieve self-sufficiency. Micro finance through SHGs also helps in the promotion of micro enterprise in terms of assets building. It will help people to build human, financial and social capital for the development of micro business that will improve people's wellbeing (Schreiner, 2004). In this context, the study report of SIDBI found that with micro credit support, clients have either started new or expanded existing enterprises which not only provided better employment opportunities but also increased enterprise income. The study also reported that between the baseline and the end line surveys, the number of enterprises of the client households increased by 1.2 per cent while those supported by micro credit increased by 5.7 per cent.A large number of studies in this regard were undertaken in the country by several researchers and their findings are varied in nature. While some authors including (Agarwal, 1990; Bhuyan, 1997; Dhillon, 1999; Goswami, \& Gogoi, 1996; Goswami, 1986; Mahajan, 1991; Shankar, 1991; Swaminathan, 1990) found the SHG programme to be effective others like (Agarwal, 1990; Dreze, 1990; Goswami \& Gogoi, 1996; Rath, 1990 and Swaminathan, 1990) got different results. The survey of some studies revealed that the procedure followed for the selection of beneficiaries in the North Eastern States, Bihar, Gujarat, Kerala, Punjab and U.P. were not proper and monitoring, follow up action and supervision of the programme were totally absent (Das,1989; Dreze, 1990; Goswami \& Gogoi, 1996; Hirway, 1984; Mahajan, 1991). Describing the potential and importance of micro enterprise and microfinance, Rangarajan, (2005)stated that 'If a serious impact on the economic conditions of the rural poor has to be made, a much larger flow of credit to support a much broader production base is required. Self-help groups (SHGs) have to graduate into promoting micro enterprises. Though micro enterprises are not a panacea for the complex problem and chronic unemployment and poverty in rural and urban areas, yet promotion of micro enterprises is a viable and effective strategy for achieving significant gains in income and assets for poor and marginalized people'.

Mentioning the importance of MSEs in India, Awasthi, (2004) stated that 'Micro and small enterprises (MSEs) constitute an important segment of the Indian economy. Besides providing employment to nearly 25 million persons, mostly belonging to the lower range of socio economic strata in the society, the sector helps the process of economic diversification, utilization of otherwise dormant resources, balanced 
regional development, production and demand for wage goods, equitable distribution of income, and widening the base of entrepreneurial supply'.Grosh and Somolekae, (1996) tried to explore the potential of developing industrial sector from micro enterprise and stated that 'an alternative line of thinking has focused on the informal or micro enterprise sector as a possible source of industrialization. Despite the common belief that the informal sector can play such a role, very little effort among scholars has been gone into identifying specific ways through which this may happen'. There is a need for a policy support to help these micro enterprises to lead to industrialization. In India, Micro finance through SHGs has a positive growth rate but there is a wide variation among the states (Soundarapandian, 2006) and linkages of banks with the SHGs are found impossible for this variation. It is reported that, only $15 \%$ of the matured SHG members had graduated to micro enterprises (Chowbey and Mishra, 2006). Difficulties in getting adequate credit, low level of awareness and lack of skills were the main reasons for not graduating to micro-enterprises. Those $15 \%$ who had graduated to micro-enterprises were still at the nascent stage and their business size was not economically viable.Micro-enterprise development and microfinance has been widely adopted as anti-poverty strategies in most of the developing countries. Micro enterprises have been accepted as the engine of economic growth and for promoting equitable development. Women owned businesses are one of the fastest growing sectors of micro-enterprises. Economic growth, stability and equity can be achieved significantly through micro-enterprises (Krishna, 2007). Micro-enterprises encourage self-employment to a large extent. Micro enterprise development helps micro-entrepreneurs combine their knowledge and determination with microfinance services to attain standard of living and generate income through business (Villar, 2008).The micro entrepreneurships are strengthening the women empowerment and remove the gender inequalities.Micro-enterprises had become of increasing importance in the economic and social development (Mungaray, et al., 2007).

This has led policy makers to view their support as a strategy for poverty alleviation in developing countries. The promotion of micro enterprises is a viable and effective strategy for achieving significant gains in income and assets for poor and marginalized people (Rangarajan, 2005). Self Help Group's micro credit mechanism makes the members to involve in other community development activities. Micro credit is promoting the small scale business enterprises and its major aim is to alleviate poverty by income generating activities among women and poor. Promotion of micro enterprises requires financial capital as one of the critical resources. Poor are the most disadvantaged in terms of access to credit through formal sources. Both market and government failed to provide access to credit to the poor. Lack of access to the credit has always been a major hindrance in promoting micro enterprises. In India, the need for micro finance is higher as the demand for credit to start micro enterprises by the poor people could not be met by the institutional initiatives of rural finance up to large scale (Singh, 2002). Further, it is observed from the study that micro enterprises which were set up by the SHGs promoted by NGOs and banks were more viable \& sustainable when compared to the micro enterprises of SHGs promoted by District Rural Development Agency (DRDA) because of differences in the quality of technical training and escort services provided to the entrepreneurs. In future, the inbuilt strength of the Self-Help Groups will pave the way to undertake mega projects, like projects performed by joint stock companies, public sector enterprise and the like the SHGs have power to create a socio-economic revolution in the rural areas India. To achieve this in practical field the conversion of consumption based self-help groups into entrepreneurship-oriented self-help groups led to employment generation and empowerment of women (Chiranjeevulu, 2003).

After studying all the literature on micro enterprise through micro finance, it is realized that almost each and every study highlighted the positive effects of micro finance through SHGs in building micro entrepreneurship in the country. A lot of study identified the problems in this connection too. Lack of marketing, poor packaging, inability to maintain standards for the products, lack of market knowledge, lack of backward and forward linkages etc. were the reasons for failure of micro enterprise at various stages. Hand holding support for quite some time to take up growth oriented micro enterprises and raising the present level of loan amount are essential for micro enterprise development.Micro-enterprise development is not a stand-alone activity. It is both efficient and cost effective to promote farm sector micro-enterprises because backward and forward linkages are locally available. Promotion of non-farm sector activities particularly those in manufacturing sector is a challenge for providing market linkages because significant sales turnover is required by each member to earn incomes which are even equivalent minimum wages or to cross the poverty line.It is obvious from the above studies that micro enterprise development had played very important role in poverty alleviation through employment and income generation. Micro enterprise and rural enterprise development programs had helped in development of 
Micro enterprises and thus enhanced investment and income of the rural poor. Micro entrepreneurship through microfinance has become a modern economic weapon for the poor to fight against poverty and unemployment. But it has long way to become successful. Many programmes from IRDP to SGSY were started by the government enthusiastically but they were not able to achieve their objectives. The reason behind this is poor follow up, lack of management and participation from the government as well people. No programme can ever get its ultimate result unless and until there is coordination and co-operation between government and beneficiaries. Table 6 depicts the number of SHGs (under SGSY) converted into a micro economic unit in India.

Table 6: Physical Progress under SGSY since Inception (Rupees in thousands)

\begin{tabular}{|c|c|c|c|c|c|c|}
\hline Years & $\begin{array}{l}\text { SHGs } \\
\text { Formed }\end{array}$ & $\begin{array}{l}\text { No. of } \\
\text { SHGs Passed } \\
\text { Grade-I } \\
\end{array}$ & $\begin{array}{l}\text { No. of } \\
\text { SHGs Passed } \\
\text { Grade-II } \\
\end{array}$ & $\begin{array}{l}\text { SHGs Taking up } \\
\text { Economic } \\
\text { Activities }\end{array}$ & $\begin{array}{l}\text { SHG } \\
\text { Swarozgaris } \\
\text { Assisted }\end{array}$ & $\begin{array}{l}\text { Individual } \\
\text { Swarozgaris } \\
\text { Assisted } \\
\end{array}$ \\
\hline $\begin{array}{l}1999- \\
2000\end{array}$ & 292 & 125 & & 29 & 35 & 586 \\
\hline $\begin{array}{l}2000- \\
2001\end{array}$ & 223 & 214 & 74 & 26 & 319 & 687 \\
\hline $\begin{array}{l}2001- \\
2002\end{array}$ & 434 & 176 & 54 & 31 & 365 & 573 \\
\hline $\begin{array}{l}2002- \\
2003\end{array}$ & 399 & 190 & 95 & 36 & 414 & 412 \\
\hline $\begin{array}{l}2003- \\
2004\end{array}$ & 392 & 205 & 91 & 51 & 578 & 320 \\
\hline $\begin{array}{l}2004- \\
2005\end{array}$ & 266 & 220 & 106 & 68 & 789 & 327 \\
\hline $\begin{array}{l}2005- \\
2006\end{array}$ & 276 & 211 & 92 & 80 & 873 & 278 \\
\hline $\begin{array}{l}2006- \\
2007\end{array}$ & 246 & 222 & 156 & 138 & 1472 & 220 \\
\hline $\begin{array}{l}2007- \\
2008\end{array}$ & 306 & 251 & 117 & 181 & 1154 & 254 \\
\hline $\begin{array}{l}2008- \\
2009\end{array}$ & 298 & 201 & 62 & 46 & 557 & 117 \\
\hline
\end{tabular}

Source: Compiled from Ministry of Rural Development, Government of India, 2008.

Prime Minister Task Force on Micro, Small and medium enterprises, Govt. of India, (2010), recommended that a Standing Review Committee under Member (Planning Commission) should be set up to monitor flow of credit to MSME sector and its apportionment to the more vulnerable sections like micro enterprises and the unorganized sector. Government should encourage Micro Finance Institutions (MFIs) to form self-help groups and finance micro enterprises in unbaked areas at reasonable rates. Banks may also be encouraged to formulate schemes for refinancing loans taken by the MSMEs from noninstitutional sources and moneylenders. Financial outreach is likely to prove an effective means to formalize the unorganized sector. Suitable incentives, including tax concessions, should be extended to MFIs to encourage them to work as business correspondents and business facilitators for banks to service micro enterprises.

Key Areas of Micro-Enterprise Development: Depending on number of factors ranging from landholdings, subsidiary occupations, agro climatic conditions and socio-personal characteristics of the rural women and her family member the areas of micro-enterprises also differ from place to place. From the survey of literature the micro enterprises are classified under three major heads:

- Micro Enterprise development related to agriculture and allied agricultural activities: like cultivating to organic vegetables, flowers, oil seeds and seed production are some of the areas besides taking up mushroom growing and bee - keeping. Some more areas can be like dehydration of fruits and vegetables, canning or bottling of pickles, chutneys, jams, squashes, dairy and other products that are ready to eat. 
- Micro-Enterprise development related to livestock management activities: like dairy farming, poultry farm, livestock feed production and production of fertilizer composting using the animal waste can be an important area in which women can utilize both her technical skills and raw materials from the farm and livestock to earn substantial income and small scale agroprocessing units.

- Micro - Enterprise development related to household based operations: like knitting, stitching, weaving, embroidery, bakery and flour milling, petty shops, food preparation and preservation.

Strategy for Micro Enterprise Development: In explaining the strategy for micro entrepreneurship development various researchers identified various approaches. Here in this paragraph, an effort is made to give a comprehensive idea about that approaches. In fact, the micro enterprise development was seen as an emerging process, which would start with low risk and low profit in the initial stage that will gain momentum and later scale up to greater capital, risk and profit. A comprehensive approach for Micro enterprise development (Mahajan, 2005) which included financial services, infrastructure finance, agricultural and business development services and institutional development services for realization of livelihood enhancement. Committed efforts were needed to promote micro enterprises such as EDP training, skill training, micro finance and marketing tie-up and all these should be available under one roof (Loganathan, 2007). Another significant strategy (Naqvi, 2007)for micro enterprise development is the gradual shift from micro-credit to livelihood to micro-enterprise, enabling environment and choices and voices for micro-enterprise, federation of such SHGs and let them decide who wants to become what, based on their wealth, expertise and willingness, network of SHG to form a champion or Self-Help Community for micro-enterprise development activities, orientation on basis of micro-enterprise management and hand holding support for micro-enterprises development. Johansson, (2008) explored the implications of stakeholder theory for organizational development and contributes to the knowledge of operational stakeholder management. Stakeholder theory suggested that to be sustainable, organizations must find a balance between different stakeholder's interests. Edward and Zakkariya (2007) pointed out that Kudumbashree is a multi-sectorial women centered participatory poverty eradication movement which simultaneously aimed for economic empowerment of poor through development and nurture of thrift and credit societies and micro enterprise. The consumer orientation and the marketing mix framework enabled Kudumbashree to achieve its mission in an efficient and effective manner (Kudumbashree, 2007).

The emphasis in the Kudumbashree enterprise programme was to encourage innovative business ideas rather than on the "tried and tested" ones. A simple and practical way for identifying enterprises was devised any idea that could solve a problem existing in the society ( Problem Solving), fill the gap that existed (Gap Filling) or cater to new opportunity (Emerging Opportunities) was converted into an enterprise. But the fact is that most of the entrepreneurs were first generation entrepreneurs and this should be kept in mind while implementing the Rural Micro Enterprise (RME) programme in the country. In fact, flow of micro credit was a pushing factor for the promotion of micro enterprises (Choudhury, 2001). This was evidenced by the fact that the SHGs were the purveyors of major credit requirements of new micro entrepreneurs. Majority of the micro entrepreneurs lacked necessary skills in the chosen trade or activity. This was evidenced by the fact that some of the micro entrepreneurs had shifted their operational activity due to lack of necessary skills. Most of them started from the cadre of daily wage labor to become small business entrepreneurs. Majority of the entrepreneurs operated with narrow margins and their enterprises had low entry and exit barriers. There was the role of SHPIs for filling the short gaps relating to the market, sources of raw materials and technology up gradation and forward and backward market linkages for supply of raw materials and marketing of finished products. It is also observed from various studies that SHG promoting institutions. viz., the groups promoted and nurtured by the Commercial Bank patronage were better equipped for capacity building of SHGs and micro enterprise promotion. However, it was a matter of concern that the micro enterprise development depends on the success of the activity, role of SHPIs in providing support services to the entrepreneurs and their capacity to seek business opportunity. In this context, Grassroots Enterprise Management Services (GEMS) for women should be introduced to forward non-financial services that would help women to identify livelihood options, understand elements of management and market that impinge on sustainability of micro-enterprises as well as the transactions and process of development of microenterprises (Viswanath, 2001). 
Problems of Rural, Micro and Women Entrepreneurs: An entrepreneur may face variety of problems in the environment, which can be classified into social problems, entrepreneurial problems, financial problems and problems related to environmental support. An entrepreneur may be attacked by any single problem or there may be an interactive and cumulative effect of number of problems.Vast majorities of women entrepreneur were fighting with the problemof lack of experience. Majority of nonentrepreneurial women were not starting their income generation activity due to inconvenience in procuring raw material. Running the entrepreneur non-profitably and not being able to achieve the breakeven point leads to closure of number of entrepreneurs (Paul, 1996 and Bhandari, 1996) .The similar entrepreneurial problems are also identified by other researchers. In one recent study conducted by Kumari, \& et al., (2010)which indicates that social problems, entrepreneurial problems, financial problems and problems related to environmental support still persists in India and has not changed in last decades even the formulation and implementation of a lot of programmes.Another important problem of SHGs in the promotion of micro enterprise development in the country particularly in NER is the uneven growth of SHG movement which indirectly affects the balanced regional development issue. However, researcher (Centre for Microfinance \& Livelihood, 2009; Pati \&Lyngdoh, 2011; Singh, 2009; Meetei, 2011; Singh, 2011; Das, 2011) articulated such uneven growth which is the result of low population density, difficult and remote terrain, lack of communication, information and training etc. These above noted problems are also evidenced from the study report of SIDBI, 2008. It is reported that the proportion of new enterprises started by clients' households with micro credit support declined from $26.4 \%$ to $13.3 \%$ (SIDBI, 2008). It was further observed that, in general, the clients were not very eager to take up new enterprises with micro credit due to lack of skills and marketing problem.

Lack of Awareness about governmental programmes is another problem of women entrepreneur.A sizeable percentage of entrepreneurial and non-entrepreneurial women do not get information timely. Stimpson, (1996) and Sharma, (1997) also concluded their findings in the same tune. This indicates that there still exists a communication gap between the implementers and users after lapse of so many years. Various financial problems which are faced by entrepreneurial women includes problem in arranging finance at various stages of entrepreneurship, lack of knowledge about government and bank financing schemes, problem of margin money etc. The major problem reported by majority of the researcher is the lack of awareness about the procedure of receiving finance.Another significant problem of rural, micro and women entrepreneur is the poor delivery system of SHGs. It is reported that the performance of SGSY was unsatisfactory in the states withhigh incidence of poverty such as Assam, Madhya Pradesh, Orissa, Jharkhand, Chattisgarh, West Bengal and Bihar. The constraintsunderline their poor performance mostly relate to the delivery system. It is also reported that inmost of the above States, functionaries of DRDAs and BDOs did notpossess adequate knowledge of the programme and also banks had littleinterest in it, line departments were hardly involved in planning, implementation and monitoring of the programme. It is observed that the bank credit in Assam was as low as Rs.665 per swarojgari. Mohamed, 2001 reported that rapid growth of rural and small scale sector were being marked by some problems i.e. technological stagnation, underutilization of capacity, lack of vertical mobility, sickness and high mortality rates, followed by shortage of finance, inadequate facilities of storage, inadequate marketing, stiff competition, low mobility, family responsibilities and social attributes.

Kollan and Parikh, (2005) reported that the problems and constraints experienced by women entrepreneur have resulted in restricting and inhibited the expansion of women enterprises. The major barrier encountered by them includes lack of confidence, working capital and knowledge, and sociocultural barriers. Women's family obligations also bar them from becoming successful entrepreneurs in both developed and developing nations. The financial institutions discourage women entrepreneurs on the belief that they can at any time leave their business and become housewives again. The result is that they are forced to rely on their own savings and loan from relatives and family friends. Another argument is that women entrepreneurs have low-level management skills. They have to depend on office staffs and intermediaries, to get things done, especially, the marketing and sales side of business. Here, there is more probability for business fallacies like the intermediaries take major part of the surplus or profit. Singh, 2008 articulated a few challenges that are faced by women entrepreneurs in India which includes lack of visibility as strategic leaders, differential information and assistance needs, family influences on women entrepreneurs etc. The study also reported attitudinal discrimination, apathy from bank officials and lack of managerial knowledge etc. stand in the way of women entrepreneurs. Knowledge of alternative source of raw materials availability and high negotiation skills etc. are the basic requirement to run a business. Getting the raw materials from different sources with discount prices is the factor that 
determines the profit margin. Lack of knowledge of availability of the raw materials, low-level negotiation and bargaining skills etc. are the factors which affect women entrepreneur's business adventures. In fine, the major problems that are faced by women, rural and micro entrepreneurs in India and North Eastern Region in particular includes

- Perceived high risk of micro entrepreneurship and small business.

- High cost involved in small lending.

- Poor institutional viability of micro enterprises.

- Lack of funds for MFIs to pass on the poor.

- Difficulty in measuring the social performance of MFIs.

- Lack of knowledge about micro finance services.

- Problem of marketing.

\section{Conclusion}

Entrepreneurship among women, no doubt improves the wealth of the nation in general and of the family in particular. Women today are more willing to take up activities that were once considered the preserve of men, and have proved that they are second to no one with respect to contribution to the growth of the economy. Women entrepreneurship must be moulded properly with entrepreneurial traits and skills to meet the changes and challenges in the global markets and also be competent enough to sustain and strive for excellence in the entrepreneurial arena.The following key strategies are suggested after due study based on survey of existing literature and hope this may help to foster women, rural and micro entrepreneurship in India in general and in NER in particular.

- Promoting women entrepreneurs in micro enterprises: An increasingly large number of women in India are engaged in the informal economy and operating in the small scale sector, cottage industries, and micro enterprises. With proper governmental and societal support, these women can create sustainable, organized and growth oriented enterprises with a long vision. Necessary government and non-governmental intervention is necessary to bring them into the ambit of registered sector in a phased manner.

- Institutional and policy based support: Government policies and regulations regarding business and industry can be formulated with the intent to encourage rural, micro \& women entrepreneurs. There should be a system of reviewing the existing regulatory framework, and make necessary correction. Secondly, the administrative hurdles that have been facing by these entrepreneurs must be simplified. Thirdly, introduction of simplified and confessional financing for women \& rural entrepreneurial project. Finally, promotional and motivating ways for women \& rural entrepreneur needs to be undertaken particularly from women's organizations \& NGO's.

- Creating awareness \& providing information: Creating massive awareness among the poor, motivation to them and developing their confidence are more important. They should make aware of various alternative of individual projects feasible in their locality and possible by tuning their ideas \& capabilities. Special camps, orientations programmes etc. should be conducted to make aware the public about micro credit and micro entrepreneurship.

- Up-scaling the provision of micro finance: Up-scaling the provisions of micro finance in India are essential for future success. Gibbons, 2002; Nair, 2005 and many more also forwarded the same view about the up scaling. However, any effect at up scaling, thus, needs to be viewed with caution as it could actually lead to increased failures \& credit indiscipline in the field.

- Directing women entrepreneurs into high growth areas: Another main part of the strategy must be to facilitate the entry of women entrepreneurs into the areas where high growth is expected. Special incentives, tax rebate/holidays, duty cuts and subsidized plant and machinery can be provided to encourage women in emerging sectors.

- Education and training programme: Higher educational incentives for rural women and advanced training programme for development of managerial and technical skills among rural women is a must. Existing women's organization and women cells may come forward in this direction to forward this type of advanced training programme in association with the existing EDP institute. 
- Private Sector Participation: Private sector can also contribute in its own way to women's entrepreneurial participation in the economy. They can provide various support services to the women entrepreneurs in respect of disseminating information and can help in the capacity building of the entrepreneurs.

- Providing necessary infrastructure for capacity building: The success of micro credit, in fact, depends upon the state of infrastructure available in the locality. Well integrated banking institutions, transport \& communication, marketing avenues etc. are very much essential for the success of micro credit. Therefore, ensurement of well-developed capacity building and supportive measure is necessary for long term development of micro credit and for entrepreneurship in the country.

- Management of SHGs and operational efficiency: Formation of SHGs and financing to them by banks and MFI only will not help much to bring success and solve the problem of rural or micro entrepreneurship. Formation of group of equally minded people, constant motivation to them to confine the saving irrespective their difficulties, selection of projects on consensus of members, and access to credit are essential for starting up a self-employed income generating enterprise. Therefore, MFI/Banks/ SHPIs should play a key role in formulation, project evaluations and study the viability of SHGs to establish project is a must.

- Providing supporting or related services: As in various studies particularly Mahajan, (2005) observed that besides micro finance, the poor also requires other financial and support services to be graduated from the poverty. Other inputs \& services are required to generate income. Therefore, ensurement in the supply of related services to the poor is essential for the successful implementation of micro finance and most particularly for establishing micro enterprises.

Further Suggestions

- SHG members must be equipped with sufficient capacity to withstand the acute competition in the market where they have to compete. Therefore, training on skill development, marketing development etc. is necessary to curve that problem by the micro finance providers.

- MFIs can give consultancy to their clients in selecting the micro enterprise particularly to ensure viability and feasibility of the projects.

- Another suggestions may be put forwarded in this direction is that there should a system of periodical monitoring \& evaluation by SHPIs in order to assess the impact.

- Another suggestion forwarded here to evaluate the operational and financial efficiency of the projects on interim basis. Concerned Area Supervisors or representatives from banks could help them in performing such tasks.

- As it is observed from the various studies that most of the products of micro enterprises are highly demanded on township, actually away from locality, hence to increase the sales volume, SHPIs can give some support in the distribution and marketing of products to the centers of demand.

\section{References}

Agarwal, A.K. (1990). The Experience with Development in Arunachal Pradesh. Journal of North Eastern Council, 2(4), 52-78.

APMAS. (2009). Quality and Sustainability of SHGs in Assam. Retrieved from http:/www.apmas.org

Aruna, K. \& Joythirmayi, D. (2011).The role of micro finance in women empowerment: A study on SHGBank linkage programme in Hyderabad.Indian Journal of Commerce and Management Studies, 11(4), 77-89.

Awasthi, D. (2004). Labour process and productivity in Micro and small enterprises: The Indian Experience. The Indian Journal of Labour Economics, 47(4), 34-42.

Bhandari, K. (1996). Participation of Rural Artisan Couples in Selected Trade and Problems by Them. M.Sc. Thesis, Bikaner: Unpublished.

Bhuyan, K. (1997). Credit Utilization Pattern of IRDP Beneficiaries of Darrang District, Assam. Journal of NEICSSR, 21(1), 34-56.

Biswas, T. \& Sengupta, P. P. (2009). Role of Microfinance in Promoting Micro entrepreneurship: The Indian Experience. International Journal of College Science in India, 3(2), 72-89.

Bokil, M. (2005). Ending Domestic Violence: SHGs can help. Pune, Development Support Team, 32.Centre for Microfinance \& Livelihood, 2009Guwahati.CML Quarterly, 1(1), 8-23. 
Chiranjeevulu, T. (2003). Empowering Women through Self-help Groups.Kurukshetra, 51(5), 16-19.

Choudhury, R.C. (2001). Micro Credit interventions in promoting Micro enterprises. NIRD research project No 21. National Institute of Rural Development, Rajendra Nagar, Hyderabad.

Chowbey, M. \& Mishra, B. L. (2006). Study on scope for promoting Micro-Enterprises activities through SHGs in selected districts of Bihar and Uttar Pradesh. Centre for Microfinance Research, Bankers Institute of Rural Development, Lucknow \& Chandragupt Institute of Management, Patna.

Das, A.P. (1989). Rural Development in Arunachal Pradesh with Special Reference to IRDP. Perspective Issues and Experiences of Rural Development in North East India, Shillong.

Das, D. (2011). Microfinance in Assam: An Overview Microfinance in North East. BIRD \& IIBM, Guwahati.

Das, S. K. (2010). Micro finance and NER-A Review. DGCC's Journal of Commerce, 7(1), 106-120.

Dreze, J. (1990). Poverty in India and the IRDP Delusion. Economic and Political Weekly, 25(39), 43123423.

Edward, M. \& Zakkariya, K.A. (2007). Study on Scope for Promoting Micro-enterprises activities. Retrieved from http://www.birdindia.org.in

Gibbons, D. S. (2002). The CFTS story. Mimeo, November.

GOI. (2001). Ninth Five Year Plan Document, GOI, Approach paper, Government of India.Retrieved from http://www.nic.in

Govt. of India. (2010). Report of the Task Force on MSME. Retrieved from http://www.pib.nic.in/newsite.

Goswami, A. \& Gogoi, J.K. (1996). India's Rural Development Programmes with Special Reference to IRDP in Assam. Rural Development in North East India. B.R. Publishing Corporation, New Delhi.

Goswami, P.C. (1986). Problems of Rural Sector Development in North-East India. Journal of North Eastern Council, 2(5). 46-67.

Grosh, B. \& Somolekae, G. (1996). Mighty Oaks from little acorns: Can micro-enterprise serve as the seedbed of industrialization. World Development, 24(12), 1879-1890.

Gurumoorthy, T. R. (2002). SHGs-Economic Empowerment through Self-Reliance. Social Welfare, 49(7), 14-17.

Hariss, J. (2010). Antinomies of Empowerment- Observations on Civil Society, Politics and Urban Governance in India. Economic and Political Weekly, June 30, 2007.

Hirway, I. (1984). Garibi Hatao: Can IRDP Do It? Economic and Political Weekly, March 30.

Jeyaseelan, N. (2007).Micro enterprise development for matured MF clients experiences solution exchange for microfinance community. Retrieved from http://www. Solution exchange.org.in

Jha, B.K. (2009).Women Empowerment: Globalization and Opportunities in Empowerment of Rural Women in India, Kanishka Publishers, New Delhi.

Johansson, P. (2008). Implementing Stakeholder Management: A Case Study at a Micro-enterprise. Measuring Business Excellence, 12(3), 33-43.

Kamaraj, J.M.A. (2005). Self-Help Groups New Mantra for Empowerment. Readers Shelf, 2(2), 13-16.

Khanka, S.S. (2004). Entrepreneurial Development. S Chand \& Co Ltd, New Delhi.

Kollan, B.I. \& Parikh, I. J. (2005). A refection of Indian women in entrepreneurial world. IIM, WP2005 (1).

Krishna, S. (2007). Self- Help Groups: In the Context of Microfinance, ICFAI, 181-192

Kudumbashree website. (2007).Retrieved from http://en.wikipedia.org/wiki/ Kudumbashree_Mission

Kumari, S., Kaushik, V. \& Lodha, N. (2010). Problems Faced by Rural Women Entrepreneurs of Rajasthan. Home Commercial Science, 4(2), 115-119.

Loganathan, K. (2007). Micro enterprise development for matured MF clients. Association for sustainable community development. Retrieved from http://www. researchgateway.org.in

Mahajan, R.K. (1991). Integrated Rural Development Programme- A Study of Problems and Prospects in Punjab, Concept Publishing Company, New Delhi.

Mahajan, V. (2005). From Micro credit to livelihood finance. Economic \& Political Weekly, 27(41), 44164419.

Mali, D.D. (2000). Entrepreneurship Development in North East. Indian Institute of Entrepreneurship, Guwahati.

Manimekalai, N. \& Rajeswari, G. (2000). Empowerment of Women through Self-help Groups. Margin, 32(4), 74-77.

Meetei, K. I. (2011). The impact of MF accessibility through group initiative to Rural Women in Manipur A case study. Microfinance in North East. BIRD\& IIBM, Guwahati.

Meher, S. (2003). SHGs and poverty in Orissa. Nabakrushna Choudhary Centre for Development Studies, Bhubaneswar: 142. 
Mishra, S.K. (2007). Recent Trend of Village and Small Enterprise Sector Exploring and Exploiting its Opportunities in the North Eastern Region of India touching upon its Profile and Barriers, Social Science Research Network. Retrieved from http:// www.nehu-economics.info/north_east.htm.

Mohamed, H.S. (2001). Problems of Rural Industries. Kisan World, 28(2).

MSME India Report. (2010). GOI. Retrieved from http://www.dcmsme.gov.in/ssiindia

Mukerjee, T. (2006). Impact assessment study of SGSY programme on empowerment of women at Babpur village. Vidyasagar School of Social Work, 5(1).

Mungaray, A., Ramirez-Urquidy, M., Texis, M., Ledezma, J. D. \&Ramirez, N. (2007). Promoting learning in small entrepreneurs and higher education students through service learning programs. International Journal of Business Research, VII (3), 10-28.

Nair, T. S. (2008). The Transforming world of Indian Micro finance. Economic \& Political Weekly, 27(17), 1695-1698.

Naqvi, S. H. (2007). Micro enterprise development for matured MF clients' .CARE India, Rajesthan.

National Commission for Women. (2004). Effectiveness of women SHG in Micro enterprises development in Rajasthan and Tamil Nadu. New Delhi. 202-253.

Nazar, M. (2005).Women entrepreneurship and small scale industries, Himalaya Publishing House, New Delhi.

Otero, M. \&Rhyne, E. (1994). The New World of Microenterprise Finance, Kumarian Press, West Hartford.

Parson, T. \& Smelser, N. J. (1956). Economy and Society. The Free Press, New York.

Pati, A. P. \& Lyngdoh, B. F. (2011). Microfinance and Socio-economic change: an Assessment of Meghalaya. Microfinance in North East. BIRD \&IIBM, Guwahati. Seminar proceedings retrieved from http:// www.birdindia.org.in/.../proceedings

Paul, E. (1996). Entrepreneurship Development, Himalaya Publishing House, New Delhi.

Purushotham, P. (2004). Micro Credit from Micro Enterprise- in Rural Non-farm Employment. Rajendranagar, NIRD. Retrieved from http.//www.nird.org.in

Rajendran, K. \& Raya, R. P. (2010). Impact of micro finance: An empirical study on the attitude of SHG leaders in Vellore districts of Tamil Nadu.Global Journal of Finance and Management, 2(1), 59-68.

Ramesh, D. (2004). Transformation of Rural Women through Micro Credit. SEDME. Retrieved from http.//www.sedme.org.in

Rangarajan, C. (2005). Microfinance and its future directions. High level Policy Conference on microfinance in India, New Delhi. Retrieved from http.//www.microfinance.org.in

Rath, N. (1990). Garibi Hatao: can IRDP Do it? In D.R. Shah (eds.) Alternatives in Development, Startling Publishers Pvt.Ltd.

Ravi, R. V. \& Venkataramana, M. (2002). Empowerment of women through SHG: a micro level study in AP. Council for Social Development, 53

Reddy, C.S. (2005). Self-Help Groups: A Key Stone of Microfinance in India-Women Empowerment and Social Security, 1-19.

Reddy, G.N. (2002). Empowering women through SHGs \& micro credit. Journal of Rural Development, 21(4), 34-54.

Roy, S. (2011). Extending microfinance services through SHGs: An Assessment of Self Help Groups particularly Assam. Microfinance in North East. BIRD \& IIBM. Guwahati.

Sathiabama, K. (2010). Rural Women Empowerment and Entrepreneurship Development.ess Scholar Journal, 6(2), 42-56.Retrieved from http.//www.ess.student.

Schreiner, M. \& Woller, G. (2003). Micro-enterprise development programs in the United States and in the developing world. World Development, 31(9), 1567-1580.

Schreiner, M. (2004). Support for Micro-enterprise as Asset-Building: Concepts, Good Practices, and Measurement. Center for Social Development, Washington University, Saint Louis.

SGSY. (2009).Report of the Committee on Credit related issues under SGSY. Department of Rural Development, Ministry of Rural Development Government of India.

Shankar, K. (1991). Integrated Rural Development Program in Eastern U.P. Economic and Political Weekly, 26(41), 2341-2357.

Sharma, R. (1997). Economic feasibility of establishing a small scale fruit and vegetable processing unit. MSc Thesis, Harayanna Agriculture University. Unpublished.

SIDBI. (2008). Assessing Development Impact of Micro Finance Programmes - Findings and Policy Implications. National Study of Indian Micro Finance Sector, Agricultural Finance Corporation Limited and DFID, UK.

Singh, N. (2002). Building Social Capital through Micro-Finance: A Perspective on the Growth of MicroFinance Sector with Special Reference to India. Retrieved from http://www.sasnet.lu.se 
Singh, N. T. (2009). Micro Finance Practices in India: An Overview.International Review of Business Research Papers, 5(5), 131-146.

Singh, P. (2009). Rural Women and Development of Entrepreneurship with special reference to Punjab in Empowerment of Rural Women in India,Kanishka Publishers, New Delhi.

Singh, S. P. (2008). An insight into the emergence of women owned business as an economic force in India. SCI -0166.

Singh, S. D. (2011).Self Help Group and Micro-enterprise Development towards Savings Habits with special reference to Manipur. Microfinance in North East, BIRD \& IIBM. Guwahati. Seminar proceedings retrieved from http:// www.birdindia.org.in/.../proceedings

Siwa, V. (2008). Gender framework analysis of empowerment of women: a case study of Kudumbashree programme. NIPCCD, New Delhi, 85

SIDBI. (2008). Assessing Development Impact of Micro Finance Programmes - Findings and Policy Implications from a National Study of Indian Micro Finance Sector. Agricultural Finance Corporation Limited, SIDBI and DFID, UK.

Smita G.S. (2006). Self-Help as a Strategy for Women's Development in India, University of Melbourne, Australia, 1-26.

Soundarapandian, M. (2006). Micro Finance for Rural Entrepreneurs Issues and Strategies, Kurukshetra, September, 12-14.

Stimpson, D.V. (1996). Attitudinal characteristics of male and female entrepreneurs in USA \& India.Journal of Psychological Studies, 38(2), 64-68.

Sundari, S. \&Geetha, N. (2000) .Poverty Credit and Micro Enterprises. Kurukshetra, 49(2), 26-32.

Swaminathan, M. (1990). Village Level Implementation of IRDP- A Comparison of West Bengal and Tamil Nadu.Economic and Political Weekly, 25(13), A17-A27.

Titus, A. P. S. (2002). Promotion of Women Entrepreneurs through Self-Help Groups. The Journal of Rural Economy, 59 (2), 68-72.

Tuladhar, G. (1996). Factors affecting women entrepreneurship in Small and cottage industries in India: Opportunities and constraints. Retrieved from http:///www.gobalhemp.com/news.

Viswanath, V. (2001). Women's Micro-enterprises for Food Security in India.Development, 44 (4), 90-92.

Villar, S. M. D. (2008).The micro enterprise promise: Creating Opportunities for low income individuals in Eugene, Oregon and adjacent rural communities. Retrieved from http://www.scholarsbank.uoregon.edu

Vincent, G. (2004). Sustainable Micro entrepreneurship: The Roles of Microfinance, Entrepreneurship and Sustainability in Reducing Poverty in Developing Countries. Retrieved from http. // www.gdrc.org/icm/micro

Wadiniale, S. M. (2004).Slum women empowered by saving credit programme.Social Welfare, 51(5), 3135. 